\title{
PENERAPAN METODE DEMONSTRASI BERBANTU MEDIA ANIMASI SOFTWARE PHET TERHADAP HASIL BELAJAR SISWA DALAM MATERI LISTRIK DINAMIS KELAS $X$ MADRASAH ALIYAH NEGERI 1 PONTIANAK
}

\author{
Nurhayati $^{1}$, Syarifah Fadilah $^{2}$, Mutmainnah ${ }^{1}$ \\ ${ }^{1)}$ Prodi Pendidikan Fisika, FPMIPA dan Teknologi IKIP PGRI Pontianak \\ ${ }^{2}$ Prodi Pendidikan Matematika, FPMIPA dan Teknologi IKIP PGRI Pontianak
}

\begin{abstract}
Abstrak
Tujuan dari penelitian ini adalah untuk menerapkan metode demonstrasi berbantu media animasi Software PhET dalam membelajarkan materi listrik dinamis, menganalisis pengaruh penggunaan metode demonstrasi berbantu media animasi Software PhETterhadap hasil belajar siswa dan mengetahui efektifitas penerapan metode demonstrasi berbantu media animasi Software PhET dalam meningkatkan hasil belajar siswa pada materi listrik dinamis.

Metode penelitian ini yaitu metode eksperimen dengan bentuk penelitian Quasi Experimental Design (eksperimen semu) dan bentuk desain Nonequivalent Group Posttest-Only. Populasi dalam penelitian ini adalah seluruh siswa kelas X Madrasah Aliyah Negeri 1 Pontianak tahun ajaran 2013/2014 yang terdiri dari tujuh kelas. Dari tujuh kelas ini diambil dua kelas sebagai sampel teknik cluster random sampiling. Sehingga diperoleh kelas eksperimen yaitu kelas XF, kelas yang diajarkan menggunakan metode demonstrasi berbantu media animasi Software PhET dan kelas kontrol yaitu kelas XA, kelas yang diajarkan menggunakan metode konvensional. Penelitian ini dimulai dari uji coba instrumen dan pengambilan data, analisis uji instrumen dan analisis data serta uji hipotesis menggunakan $U$ Mann Whitney karena kedua data tidak berdistribusi normal. Sedangkan untuk mengetahui besar efektifitas penerapan metode demontrasi berbantu media animasi Software PhET dengan menggunakan rumus effect size. Berdasarkan hasil analisis data, diperoleh rata-rata posttest pada kelas eksperimen sebesar 72,72 sedangkan rata-rata posttest pada kelas kontrol sebesar 54,89. Hasil uji hipotesis menggunakan $U$-Mann Whitney diperoleh $Z_{\text {hitung }}=-3,198$ untuk $\alpha=5 \%$ diperoleh $Z_{\text {tabel }}$ sebesar -1,64 dengan demikian $Z_{\text {hitung }}<Z_{\text {tabel }}$ atau -3,198 <-1,64, maka dapat disimpulkan bahwa hasil belajar siswa yang diajarkan dengan metode demonstrasi berbantu media animasi Software PhET lebih baik dari pada hasil belajar siswa dengan menggunakan metode konvensional. Berdasarkan analisis data diperoleh Effect Size sebesar 0,8 maka dapat disimpulkan efektivitas penerapan metode demonstrasi berbantu media animasi Software PhET dalam materi listrik dinamis kelas X Madrasah Aliyah Negeri 1 pontianak tergolong sedang.
\end{abstract}

Kata Kunci: Metode demonstrasi, media animasi Software PhET, listrik dinamis dan hasil belajar. 


\section{PENDAHULUAN}

Pendidikan adalah usaha sadar yang dilakukan oleh keluarga, masyarakat dan pemerintah melalui kegiatan bimbingan pengajaran dan latihan yang berlangsung di sekolah dan di luar sekolah sepanjang hayat untuk mempersiapkan peserta didik agar dapat memainkan peranan dalam berbagai lingkungan hidup secara tepat di masa yang akan datang (Mudyahardjo dalam Tirtarahardja \& Sulo, 2012:165). Menurut Langeveld dalam Hasbullah (2009:2) pendidikan ialah setiap usaha, pengaruh, perlindungan dan bantuan yang diberikan kepada anak tertuju kepada pendewasaan anak itu atau lebih tepat membantu anak agar cukup cakap melaksanakan tugas hidupnya sendiri. Jadi pendidikan adalah usaha manusia untuk membina kepribadian sesuai dengan nilai-nilai di dalam masyarakat agar dapat melaksanakan tugas hidup.

Fisika adalah suatu bidang studi yang mempunyai peranan penting dalam pendidikan khususnya dalam pendidikan di sekolah. Menurut Hak (dalam Widodo, 2005:106), fisika merupakan ilmu fundamental karena merupakan tulang punggung bagi perkembangan ilmu pengetahuan dan teknologi. Mata pelajaran fisika mulai di ajarkan secara khusus kepada siswa semenjak Sekolah Menengah Pertama (SMP). Namun siswa sering mengalami kesulitan dalam pembelajaran fisika.

Berdasarkan hasil wawancara dengan guru fisika di Madrasah Aliyah Negeri 1 Pontianak, diperoleh informasi bahwa salah satu materi yang sulit dipahami siswa adalah materi listrik dinamis. Hal ini dilihat dari hasil ulangan blok dan ulangan semester siswa tentang materi listrik dinamis yang masih jauh dari kriteria ketuntasan minimal (KKM) yaitu 75 .

Berdasarkan hasil pengamatan di lapangan juga ditemukan beberapa masalah diantaranya siswa kurang aktif dalam pembelajaran fisika, banyak berbicara sendiri dan tidak mendengarkan penjelasan guru saat menyampaikan materi. Pembelajaran lebih terfokus pada guru menyebabkan siswa menjadi bosan dan tidak tertarik untuk mempelajari materi fisika yang diajarkan. Untuk menindaklanjuti masalah tersebut dibutuhkan sebuah metode pembelajaran yang terfokus kepada siswa sehingga siswa lebih aktif dalam kegiatan pembelajaran yang pada akhirnya dapat meningkatkan hasil belajar siswa.

Ada banyak metode yang terfokus kepada siswa yaitu metode demonstrasi, metode proyek, metode diskusi dan metode tugas serta resistasi. Metode demonstrasi adalah suatu metode yang cara penyajian pelajaran dengan memperagakan atau mempertunjukkan kepada peserta didik suatu proses, situasi atau benda tertentu yang sedang dipelajari baik dalam bentuk tiruan yang dipertunjukkan oleh guru atau sumber belajar lain yang ahli dalam topik bahasan (Sumantri, 2001:82). Pendapat lain menyatakan bahwa metode demonstrasi adalah metode yang digunakan untuk memperlihatkan suatu proses atau cara kerja suatu benda yang berkenaan dengan pembelajaran. Berdasarkan teori yang dijelaskan oleh para ahli, metode demonstrasi cocok digunakan pada pembelajaran fisika khususnya pada materi listrik dinamis karena materi listrik dinamis merupakan materi yang banyak menunjukkan suatu proses atau cara misalnya proses aliran elektron pada rangkaian listrik dan cara mengukur besaran-besaran listrik.

Selain itu, berdasarkan penelitian yang sudah dilakukan menggunakan metode demonstrasi dapat meningkatkan hasil belajar siswa diantaranya, penelitian Sutilawaty (2013:55) menyimpulkan bahwa penerapan metode demonstrasi efektif untuk meningkatkan hasil belajar siswa SMP pada materi fisika Hukum Archimedesdengan efektivitas penerapan tergolong tinggi yaitu dengan nilai Effect Size (ES) sebesar 0,8. Penerapan metode demonstrasi juga dapat meningkatkan aktivitas belajar siswa (Sari, dkk, 2012). Penelitian yang sama juga dilakukan oleh Wahyudidan Dinata (2013) hasil penelitian disimpulkan bahwa terdapat 
perbedaan antara hasil belajar siswa pada pembelajaran fisika menggunakan metode demonstrasi dengan media animasi yang lebih baik dari pada pembelajaran fisika menggunakan metode konvensional. Aktivitas belajar siswa selama proses pembelajaran fisika menggunakan metode demonstrasi dengan media animasi tergolong tinggi dan lebih bersikap dan bertingkah laku positif selama pembelajaran berlangsung.

Oleh karena listrik dinamis bersifat abstrak artinya tidak bisa diamati secara langsung, sehingga diperlukan media pembelajaran yang dapat mempermudah siswa dalam memahami materi yang dipelajari. Menurut Arsyad (2013:10) media pembelajaran adalah segala sesuatu yang dapat digunakan untuk menyampaikan pesan atau informasi dalam proses belajar mengajar sehingga dapat merangsang perhatian dan minat siswa dalam belajar. Banyak media yang dapat digunakan oleh guru dalam mempelajari fisika agar siswa lebih mudah memahami dan menguasai konsep dari materi yang dipelajari, salah satunya yaitu menggunakan media animasi Software PhET.

Media animasi Software PhET adalah salah satu media komputasi yang menyediakan animasi baik fisika, biologi, maupun sains lain. Di dalam media animasi Software PhET ada sub-sub file yang dapat dipilih sendiri, animasi apa yang ingin ditampilkan. Di dalam media ini dapat ditampilkan suatu materi yang bersifat abstrak dan dapat dijelaskan secara langsung oleh media ini sehingga siswa dengan mudah memahami materi tersebut misalnya aliran elektron pada rangkaian listrik dan arus listrik yang mengalir pada rangkaian tertutup .

Berdasarkan paparan yang telah dikemukakan, maka penelitian yang dilakukan ini untuk mengetahui efektivitas penerapan metode demonstrasi berbantu media animasi Software PhET dalam meningkatkan hasil belajar siswa pada materi listrik dinamis kelas X Madrasah Aliyah Negeri 1 Pontianak.

\section{METODE PENELITIAN}

Metode penelitian ini adalah metode eksperimen. Bentuk penelitian yang dipilih yaitu kuasi ekperimen dengan rancangan Nonequivalent Groups Posttest-Only (Marczyk, dkk, 2005: 138). Populasi dalam penelitian ini yaitu seluruh siswa kelas $\mathrm{X}$ Madrasah Aliyah Negeri 1 Pontianak yang yang terdiri dari tujuh kelas. Sampel dalam penelitian ini sebanyak dua kelas yaitu XA dan XFyang diambil dengan teknikcluster random sampling. Kelas XA diberi pembelajaran dengan menggunakan model konvensional dan kelas XF diberi pembelajaran dengan metode demonstrasi berbantu media animasi Software PhET. Hasil uji kesetaraan melalui uji $t$ independent sampel (Budiyono, 2009: 151) menunjukkan keadaan awal kedua kelas sampel tidak berbeda.

Data hasil belajar siswa pada materi listrik dinamis diperoleh dengan tes hasil belajar berbentuk essay. Tes berjumlah 10 soal yang diberikan sesudah permbelajaran. Sebelum soal tes digunakan terlebih dahulu ditelaah secara isi oleh para ahli dan diuji coba untuk mengetahui tingkat uji validitas dan reliabilitas (Surapranata, 2009). Soal yang digunakan dalam penelitian ini yakni soal yang kriteria valid dan memiliki reliabiltas tinggi.

Pengolahan data hasil belajar siswa diawali dengan uji prasyarat analisis berupa uji normalitas dan uji homogenitas data yang dilakukan dengan bantuan program SPSS. Uji normalitas menggunakan uji Kolmogorov-Smirnov, bertujuan untuk mengetahui sampel yang diambil berasal dari populasi yang berdistribusi normal atau tidak normal. Sedangkan uji homogenitas data menggunakan uji Levene-test dilakukan untuk mengetahui suatu sampel berasal dari populasi yang homogen atau tidak homogen. Uji prasyarat analisis menunjukkan bahwa sebagian besar data penelitian tidak berdistribusi normal dan homogen, sehingga pengujian hipotesis penelitian ini menggunakan statistik non parametrik yaitu uji $U$ Mann Whitney. Untuk mengetahui seberapa besar efektiftas penerapan metode 
ISSN: 2087-9946

demonstrasi metode demonstrasi berbantu media animasi Software PhET dalam meningkatkan hasil belajar siswa pada materi listrik dinamis, data dianalisis dengan menggunakan rumus effect size (Sutrisno, 2008). Adapun persamaan yang digunakan sebagi berikut.

$$
\mathrm{ES}=\frac{\overline{\mathrm{Y}}_{\mathrm{E}}-\overline{\mathrm{Y}}_{\mathrm{C}}}{\mathrm{S}_{\mathrm{C}}}
$$

Keterangan :

$\mathrm{ES}=$ Effect Size

$\bar{Y}_{E}=$ rata-rata skor kelompok eksperimen

$\bar{Y}_{C}=$ rata-rata skor kelompok kontrol

$S_{C}=$ standar deviasi kelompok kontrol

Dengan kriteria effect size sebagai berikut:

Tabel 1. Kriteria Effect Size

\begin{tabular}{cc}
\hline Interval & Kriteria \\
\hline \hline $\mathrm{ES} \leq 0,2$ & Rendah \\
$0,2<\mathrm{ES} \leq 0,8$ & Sedang \\
$\mathrm{ES}>0,8$ & Tinggi \\
\hline
\end{tabular}

\section{HASIL DAN PEMBAHASAN}

Tujuan dari penelitian ini adalah untuk mengetahui efektifitas penerapan metode demonstrasi berbantu media animasi Software PhET untuk meningkatkan hasil belajar siswa dalam materi listrik dinamis kelas X Madrasah Aliyah Negeri 1 Pontianak.

Data perolehan nilai rerata tes tes akhir pada kelas eksperimen dan kelas kontrol dapat dilihat pada Tabel 2.

Tabel 2. Deskripsi Nilai Hasil Belajar Siswa Pada Materi Litrik Dinamis

\begin{tabular}{cccccc}
\hline Kelompok & $\begin{array}{c}\text { Jumlah } \\
\text { Data }\end{array}$ & $\begin{array}{c}\text { Nilai } \\
\text { Tertinggi }\end{array}$ & $\begin{array}{c}\text { Nilai } \\
\text { Terendah }\end{array}$ & Rata-rata & $\begin{array}{c}\text { Standar } \\
\text { Deviasi }\end{array}$ \\
\hline \hline Eksperimen & 38 & 95,71 & 22,85 & 77,72 & 19,20 \\
\hline Kontrol & 34 & 96,00 & 21,42 & 54,89 & 22,49 \\
\hline
\end{tabular}

Berdasarkan Tabel 2,terlihat bahwa hasil belajar siswa kelas eksperimen lebih tinggi dibandingkan hasil belajar siswa pada kelas kontrol dengan rata-rata kelas eksperimen sebesar 72,72 dan rata-rata kelas kontrol sebesar 54,89. Sedangkan besarnya harga standar deviasi kelas eksperimen adalah 19,20 dan harga standar deviasi kelas kontrol adalah 22,49. Hal ini menunjukkan bahwa pada kelas eksperimen rata-rata siswa memiliki nilai yang tidak jauh berbeda dari rata-rata nilai kelasnya, atau tidak memiliki keragaman data yang besar. Sedangkan pada kelas kontrol rata-rata siswa memiliki nilai yang jauh berbeda dari rata-rata kelasnya, atau memiliki keragaman data yang besar. Sehingga standar deviasi kelas eksperimen lebih kecil dari pada kelas kontrol.

Uji prasyarat analisis meliputi uji normalitas dan uji homogenitas data. Rekapitulasihasil uji prasyarat analisis disajikan pada Tabel 3 dan Tabel 4.

Tabel 3. Hasil Uji Normalitas Data Hasil Belajar Siswa Pada Materi Listrik Dinamis

\begin{tabular}{clccc}
\hline \multirow{2}{*}{ Jenis Data } & \multirow{2}{*}{ Kelas } & \multicolumn{3}{c}{ Kolmogorov-Smirnov } \\
\cline { 2 - 5 } & & Statistic & $d f$ & Sig. \\
\hline \hline \multirow{2}{*}{ Hasil Belajar } & Eksperimen & 0,243 & 38 & 0,000 \\
\cline { 2 - 5 } & Kontrol & 0153 & 34 & 0,043 \\
\hline
\end{tabular}

Tabel 4. Hasil Uji Homogenitas Data Hasil Belajar Siswa Pada Materi Listrik Dinamis

\begin{tabular}{lcccc}
\hline \multirow{2}{*}{ Data } & \multicolumn{5}{c}{ Levene Test } \\
\cline { 2 - 5 } & Statistic & $d f 1$ & $d f 2$ & Sig. \\
\hline \hline Hasil Belajar & 3,426 & 1 & 70 & 0,068 \\
\hline
\end{tabular}


Berdasarkan Tabel 3 dan 4, diketahui bahwa nilai signifikansi untuk data hasil belajar kelas eksperimen dan kontrol lebih kecil dari taraf signifikansi yang digunakan dalam penelitian yaitu 0.05. Hal ini menunjukkan bahwa data hasil belajar kelas kontrol dan eksperimen tidah berdidtribusi normal dan berdasarkan uji homogenitas menggunakan Levene test diperoleh bahwa data homogen. Oleh karena data tidak berditribusi normal maka statistik untuk menguji hopitesis menggunakan statistik non parametrik. Adapun hasil uji hipotesis dengan menggunakan uji $U$ Mann Whitney dapat dilihat pada Tabel 5 berikut.

Tabel 5. Rangkuman Hasil Uji Hipotesis Penelitian

\begin{tabular}{cc}
\hline Dependent Variable & AsympSignifikansi \\
\hline \hline Hasil Belajar & 0,001 \\
\hline
\end{tabular}

Berdasarkan hasil analisis data uji hipotesis pada Tabel 5 untuk hasil belajar menggunakan uji $U$ Mann Whitney diperoleh bahwa nilai signifikansi adalah 0,001 (atau <0,05) maka Ho ditolak dan $\mathrm{Ha}$ diterima. Hal ini berarti hasil belajar siswa yang diajarkan dengan metode demonstrasi berbantu media animasi Software PhET lebih baik dari pada hasil belajar siswa dengan menggunakan metode konvensional.

Berdasarkan perhitungan menggunakan rumus effect size(persamaan 1) diketahui bahwa efektifitas penerapan metode demonstrasi berbantu media animasi Software PhETdalam meningkatkan hasil belajar siswa pada materi listrik dinamis tergolong sedang (Tabel 1). Hal ini menunjukkan bahwa metode demonstrasi dengan berbantu media animasi Software PhETefektif dalam meningkatkan hasil belajar siswa pada materi listrik dinamis.

Tujuan dalam penelitian ini adalah untuk mengetahui efektifitas penerapan metode demonstrasi berbantu media animasi Software PhETdalam meningkatkan hasil belajar siswa dalam materi listrik dinamis kelas X Madrasah Aliyah Negeri 1 Pontianak.

Berdasarkan hasil analisis data menggunakan statistik nonparametrik yaitu $U$ Mann Whitney diperoleh bahwa $\mathrm{Ha}$ diterima, maka dapat disimpulkan bahwa hasil belajar siswa yang diajarkan dengan metode demonstrasi berbantu media animasi Software PhET lebih baik dari pada hasil belajar siswa dengan menggunakan metode konvensional.Terjadinya perbedaan hasil belajar siswa dikarenakan metode demonstrasi berbantu media animasi Software PhET dapat menarik perhatian siswa untuk mengikuti pembelajaran dikelas dan siswa tidak hanya membayangkan secara abstrak tentang konsep materi listrik dinamis, akan tetapi siswa dapat melihat langsung konsep-konsep materi listrik dinamis yang diajarkan oleh guru. Secara tidak langsung hal ini mempengaruhi faktor-faktor dalam diri siswa yaitu minat, perhatian dan motivasi siswa untuk belajar. Hal ini sejalan dengan pendapat Anita (2008) yang menyatakan faktor-faktor yang mempengaruhi hasil belajar siswa ada dua yaitu faktor dalam diri siswa diantaranya adalah kecakapan, minat, bakat, usaha, motivasi, perhatian, kelemahan dan kesehatan, serta kebiasaan siswa, dan faktor dari luar siswa yang mempengaruhi hasil belajar diantaranya adalah suasana kelas dalam belajar, seperti riang gembira dan menyenangkan. Selain itu dengan menggunakan metode demonstrasi, siswa akan memperoleh gambaran yang lebih jelas mengenai konsep-konsep materi listrik dinamis yang didemonstrasikan, perhatian siswa akan lebih mudah dipusatkan, dapat merangsang siswa untuk lebih aktif dalam mengikuti proses belajar dan bisa membuat siswa ingat lebih lama tentang materi yang disampaikan.

Penggunaan media animasi Software PhET juga dapat memberikan pengalaman menarik kepada siswa saat proses 
pembelajaran, mendidik siswa agar memiliki pola berpikir konstruktivisme, membuat pembelajaran lebih menarik karena siswa dapat belajar sekaligus bermain pada simulasi tersebut dan dapat memvisualisasikan konsep-konsep fisika. Karena itu proses pembelajaran harus memberikan pengalaman belajar yang baik kepada siswa (Aunurrahman, 2010:17). Hal ini yang mendukung bahwa dengan menerapkan metode demonstrasi berbantu media animasi Software PhET dalam materi listrik dinamis kelas X Madrasah Aliyah Negeri 1 Pontianak dapat meningkatkan hasil belajar siswa.

Sementara itu, dari hasil perhitungan effect size diperoleh harga effect size (Es) sebesar 0,80 maka berdasarkan kriteria yang berlaku harga effect size tergolong sedang dengan kriteria pada Tabel 1. Sehingga besar penerapan metode demonstrasi berbantu media animasi Software PhETefektif dalam meningkatkan hasil belajar siswa pada materi listrik dinamis.

\section{SIMPULAN DAN SARAN}

Berdasarkan penelitian yang telah dilakukan, dapat disimpulkan bahwa

1) Hasil belajar siswa yang diajarkan dengan metode demonstrasi berbantu media animasi Software PhET lebih baik dari pada hasil belajar siswa dengan menggunakan metode konvensional. Pembelajaran dengan menggunakan media animasi Software PhETdapat menumbuhkan motivasi belajar siswa pada materi listrik dinamis.

2) Penerapan metode demonstrasi berbantu media animasi Software PhET efektif dalam meningkatkan hasil belajar siswa pada materi listrik dinamis dengan kategori efektifitas sedang.

Berdasarkan hasil peneltian dan pembahasan yang telah dilakukan, peneliti menyarankan hal-hal sebagai berikut.

1) Hendaknya, waktu pelaksanaan pembelajaran tidak hanya sebatas dua kali pertemuan tetapi empat kali pertemuan, agar dapat memperoleh data yang dapat menggambarkan keadaan yang sebenarnya.

2) Perlu dilakukan penelitian tentang faktor-faktor lain yang berpengaruh terhadap prestasi belajar, sehingga dapat menambah pengetahuan guru dalam upaya meningkatkan prestasi belajar siswa.

\section{Daftar Pustaka}

[1] Anita, S, \& Rusman. 2008. Strategi Pembelajaran di SD. Jakarta: Universitas Terbuka.

[2] Arsyad, A. 2013. Media Pembelajaran. Jakarta: Rajagrafindo Persada.

[3] Aunurrahman. 2010. Belajar dan Pembelajaran. Bandung: Alfabeta.

[4] Budiyono. 2009. Statistik untuk Penelitian Edisi Ke-2. Universitas Sebelas Maret Press: Surakarta.

[5] Marczyk, G., DeMatteo, D., \& Festinger, D. 2005. Essential of Research Design And Methodology. USA: John Wiley \& Sons, Inc

[6] Sari, T.A., Bektiarso, S, dan Yushardi. 2012. Penerapan Model Pembelajaran Generatif dengan Metode Demonstasi dalam Pembelajaran Fisika di SMP. Jurnal Pembelajaran FisikaUNEJ, Vol.1 No.2, hal 145-151.

[7] Sumantri, M. 2001. Pengertian Metode Demonstrasi. [Online]. Tersedia: http://www. Elfitriastikawati. Blogspot.com /2012/09. html [2 Februari 2014].

[8] Surapranata, S. 2009. Analisis, Validitas, Reliabilitas dan Intepretasi Hasil Tes-Implementasi Kurikulum 2004. Remaja Rosdakarya: Bandung.

[9] Sutilawaty, C. 2013. Penerapan Metode Demonstrasi Pada Materi Hukum Archimedes Di Kelas VIII SMP Bina Utama Pontianak. Skripsi pada STKIP-PGRI Pontianak: tidak diterbitkan.

[10] Sutrisno, Leo. 2008. Remediation of Weaknesses of Physics Concepts. Pontianak: Untan Press. 
[11] Tirtarahardja \& Sulo. 2008. Pengantar Pendidikan. Jakarta: Asdi Mahasatya.

[12] Wahyudi, \& Dinata, W.A. 2013. Pembelajaran Fisika Menggunakan Metode Demonstrasi dengan Media Animasi pada Materi Konsep Zat di Kelas VII SMPN 4 Pontianak. Jurnal
Pend. Informatika dan Sains, Vol.2, No.2, hal 187-200.

[13] Widodo, B. 2005. Pengembangan Model Pembelajaran Kooperatif Model STAD Mata Kuliah Fisika Matematika Mahasiswa Program Studi Pendidikan Fisika. Jurnal $\begin{array}{llll}\text { Varidika, } & 17 & \text { (2), 106-108 }\end{array}$ 